\title{
The eye in the stomach
}

$\mathrm{T}$ he young nurse inquired congenially: "Have you ever had an endoscopic examination?"

"No," I replied, "but my frien ..."

"Open your mouth, please," she interrupted as she sprayed a liquid into my mouth from what looked like a silver oil can circa 1914. "This will freeze your throat."

"Ohhkaa."

"You'll feel it swelling up in a few ..."

"Ah, ah kan swalo!" I gasped, clutching spasmodically at my throat.

"... seconds."

It felt like someone was inflating a balloon in my throat.

"Need to spit?" she asked.

Too late, a string of saliva had already drooled from my mouth to my chin and onto my shirt. cally.

"Sawiee," I said apologeti-

She smiled sympathetically, "It's a simple procedure that won't take too long. The doctor will do an exploratory examination of your stomach. He'll be able to see by monitoring your stomach with the assistance of a mini-cam attached to the end of this tube."

"Wah do yu pu tha?" came my response.

"We place it down your throat," she said frankly.

I raised the proverbial eyebrow. I have difficulty swallowing an aspirin and they want to shove a garden hose down my gullet for a "quick" peek. Then the banter faded into an earnest silence. I hate earnest silence because it usually means something unpleasant is going to happen. Five minutes later, I look as though I'm doing the sidestroke in a pool of my sweat - teeth clamped on a plastic mouthpiece. My hand was slapped away each time I moved to pull the tube out — and they were just sticking it into my mouth.

"It only feels uncomfortable initially," assured the doctor, forcing it down with grim determination.

Each time the tube was moved or pushed further down, an ugly, sonorous belch-like heave gurgled up every four seconds, faster than air from a whoopee

as I gave a weak victory smile. I looked like Peter Sellers in The Party dying to pee while feigning a smile to the other guests.

"Well, you have an active ulcer," said the doctor as though he had just discovered his lost lottery ticket.

"I coda tool yu tha myself," I said in a dazed stupor.

"Sorry?" he replied while he scribbled some medical hieroglyphic prescription on a pad of paper.

"Oh, really?" I responded.

In a chirpy, confident manner he continued: "Yes, probably permanent. I want you to take these pills — one every day."

Apprehensively I asked, "For the rest of my life?"

The doctor must have sensed my anxiety for he continued. "For a month,

cushion. My mouthpiece popped from my mouth like I had been punched in the stomach. The kind nurse replaced it back in my mouth like a gag, held my clinched hand - the only redeeming consolation - and cooed for me to keep breathing normally through my nose and to relax. Relax? It felt like a David Attenborough documentary - a scrutiny of prods here, an "Ohh" and an "Ahh" there. A chuckle there. It felt like an eternity. I was hoping a quick Polaroid snapshot would be sufficient, but the doctor was probing around as though learning to do a three-point turn with Mr. Magoo as his instructor. Finally, the tube was removed - like air out of a tire. Everyone was cheerful and self-congratulatory while I sprawled on the gurney like a fish out of water.

"Well done, Clive," said the nurse soothingly.

I think that "Than yu," dribbled out of my mouth. Pebbles of sweat soaked my skin. Tears streamed down my eyes then whenever you feel the burning sensation. However, if it gets worse ..." Then those five dreaded words came out like a Gatling gun. "We will have to operate."

"Every patient has reacted the same way you did," the nurse consoled. "Except one - a young girl — who never even flinched."

Probably passed out I thought. Not that that made me feel any better. I felt a lot worse leaving the hospital than when I came in. My throat felt like I had a puffer fish lodged in my larynx and that someone was excavating for oil in my stomach. Still, I shouldn't complain. My options could have been a tube through my nose, penis or rectum. Modern medicine. What a marvel!

\section{Clive Branson BA}

Owner and Creative Director

Provocadv

Ottawa, Ont.

CMAJ 2011. DOI:10.1503/cmaj.101862 